\title{
ЯЗЫКОВЫЕ СРЕДСТВА ФОРМИРОВАНИЯ КОНЦЕПТА «СТАРИНА» В РАССКАЗЕ П.И. МЕЛЬНИКОВА-ПЕЧЕРСКОГО «СТАРЫЕ ГОДЫ»
}

\author{
Романенко Виктория Андреевна \\ к. филол. н., доцент кафедры русского языка \\ и межкультурной коммуникации \\ Приднестровский государственный университет им. Т.Г. Шевченко
}

Аннотация: Настоящая статья посвящена описанию языковых средств формирования концепта «старина» на материале рассказа П.И. МельниковаПечерского «Старые годы». Так как научных работ, посвященных выявлению роли языкового материала в формировании концепта «старина» на данном материале не обнаружено, в этом и заключается научная новизна и актуальность исследования.

Ключевые слова: концепт, архаизмы, историзмы, диалектизмы, экзотизмы

\section{LINGUISTIC MEANS OF FORMING THE CONCEPT OF "OLD" IN THE STORY OF P.I. MELNIKOV-PECHERSKY "OLD YEARS"}

\section{Romanenko Victoria Andreevna}

Abstract: This article is devoted to the description of the linguistic means of forming the concept of "antiquity" based on the material of the story by P.I. Melnikov-Pechersky "Old Years". Since no scientific papers devoted to the identification of the role of linguistic material in the formation of the concept of "antiquity" have been found on this material, this is the scientific novelty and relevance of the study.

Key words: concept, archaisms, historicisms, dialectisms, exotisms

Актуальность темы исследования состоит в отсутствии научных работ, посвященных выявлению роли языкового материала, используемого для формирования концепта «старина» в рассказе П.И. Мельникова-Печерского «Старые годы». 
Цель настоящей статьи - описание языковых средств формирования концепта «старина» на материале рассказа П.И. Мельникова-Печерского «Старые годы». Для достижения цели были поставлены следующие задачи:

1. Выявить языковые особенности речи автора и персонажей.

2. Охарактеризовать фонетические, акцентные, лексические, грамматические стилистические особенности языковой системы произведения.

3. Сформулировать вывод относительно использования писателем широкой палитры русского языка для формирования ключевого концепта рассказа.

Объектом исследования послужил рассказ П.И. Мельникова-Печерского «Старые годы», в котором, как в призме, отразилась жизнь людей разных сословий 18 века.

Предметом статьи является выявление особенностей языкового воплощения концепта «старина» в исследуемом рассказе.

Научная новизна работы заключатся в том, что в ней предпринята попытка комплексного лингвостилистического анализа текста данного произведения.

Материал статьи и ее основные выводы могут быть использованы в вузовском курсе лекций по русской литературе и филологическому анализу художественного текста.

С первых страниц повести П.И. Мельников-Печерский погружает читателя в прошлое. В сказово-повествовательной манере автор разворачивает широкое полотно быта и истории, овеянной в переложении столетнего очевидца красотой, оборачивающейся в итоге уродством помещичьего уклада. На этом антифразисе держится каркас всего рассказа. Точка зрения инклюзивного повествователя связывает прошлое и настоящее: «Довелось мне раз побывать в большом селе Заборье. Стоит оно на Волге. Место тут привольное» [1, с. 3]. В зачине форму глагола прошедшего времени - маркер присутствия рассказчика - тотчас сменяет ряд глаголов в форме настоящего времени со значением настоящего исторического. Мы видим живописную местность Заборья с крутыми берегами Волги, горами, златоглавыми церквами, городскими постройками, пристанью, пароходами и т.д. В той ж роли используется и форма будущего времени глагола: «Наступит девята пятнииа, начало ярмонке. С раннего утра в Заборье все закишит, ровно в муравейнике: в парад зачнут сбираться, пудриться, одеваться, коней седлать, кареть закладывать. И когда все по чину устроится, пойдет к князю старший 
двореикий с докладом...» [1, с. 27]. Сдержанный, неторопливый темпоритм повествования воссоздает ритм самой жизни русской старины, чему способствует разговорная и эпическая инверсия: «Стоит оно на Волге. Место тут привольное»; «...место веселое, бойкое» [с. 3]; «Запустельій, обветшальій, точно переглядывается он с древними зданиями монастырскими» [1, с. 4]; простые предложения неосложненного типа, перемежающиеся с предложениями, осложненными обособленными конструкциями, выраженными причастными и деепричастными оборотами: «На одной красуются величественные храмы XVII века, украшенные снаружи стенописью, увенчанные золотыми шатрами и куполами Величественный дворец, строенный в прошлом столетии по плану Растрелли, окруженный полуразвалившимися флигелями и службами, господствуя над Волгой $u$ Заборьем, угрюмо смотрит на новую, развивщуюся под его ногами деятельность» [1, с. 4].

Концепт «старина» оформляется эксплицитно - многократным повторением слов с корневой морфемой «-стар-» (117 однокоренных слов в тексте), о частотности и плотности использования которых свидетельствует следующий фрагмент: «Старина $u$ забылась. A долго-таки кое-что поддержсивалось. Вот и я еще помню псарню здесь, музыкантов, арапа старого да карлика - древний-надревний был. Мало-помалу переводили все, а как вотчина к Кирдяпиным перешла, все порешилось. Сами изволите знать, уж как оно ни на есть, а все чужое. Оттого и не жаль. Был здесь старик Прокофьич. Чуть-чуть его помню. Да вот уж лет сорок, как и он помер. Вот он так уж всю подноготную про здешние старые годы знал» $[1$, с. 6]. Имплицитно концепт «старина» передан словами с семой «давний», например, в анафорическим повторе наречия «давно»: «Давно свалились его двери, давно вылииблены из окон его рамыl» [1, с. 5], описанием картин запустения некогда бившей ключом жизни усадьбы: «Величественный двореи, строенный 8 прошлом столетии по плану Растрелли, окруженный полуразвалившимися флигелями и службами, господствуя над Волгой и Заборьем, угрюмо смотрит на новую, развившуюся под его ногами деятельность. Запустельй, обветшальй, точно переглядывается он $c$ древними зданиями монастырскими...» [1, с. 4]; «[...] ветер да зимние вьюги свободно гуляют по комнатам, где чего-то ни бывало в старые годы!. Плафон осыпался, но по сохранившимся остаткам заметно, что он изображал торжество Приапа...» $[1$, c. 5]. 
Предметно-рематические доминанты описательных фрагментов рассказа изобилуют денотативными рядами образов еды, одежды, охотничьего снаряжения, будничного и праздничного убранства интерьера и экстерьера, отсылающего нас в прошлое. «Богатство-то, сударь, какое, изобилие-то какое было! Одного столового серебра сто двадиать пудов, в подвале бочонки с целковыми стояли, а медные деньги, что горох, в сусеки ссыпали: нарочно такие сусеки в подвалах были наделаны. Музыкантов два хора, на псарне не одна тысяча собак, на конюшне пятьсот лошадей верховых да двести езжалых; иутов да юродивых десятка полтора при доме бывало, опричь немых арапов да карликов» [1, с. 21]. А вот характерное описание снеди: «Были тут сельди голландские, сыр немецкий, икра яикская с лимоном, икра стерляжья с перием, балык донской, колбасы заморские, семга архангелогородская, ветчина вестфальская, сиги в уксусе из Питера, грибы отварные, пироги подового дела, оладьи и пряженцы с яйщами. А в графинах водка золотая, водка анисовая, водка зорная, водка кардамонная, водка тминная, - а все своего завода» [1, с. 41]. Определения трансформируют название того или иного блюда в культурему. Вот огурцы подновские, названные так в честь села Подновье, где в 18-19 веке заготавливали соленые огурцы, чем село и прославилось [2], вот подовые пироги, обычно их в конце 18 века начиняли мясом с луком или капустой с яйцами, тесто замешивалось крутое, на говяжьем сале и кипятке, запекали в печи на сковороде. Вес одного подового пирога (примерно 20 на 10 см) достигал фунта (400 г). Подовыми они назывались потому, что испекались на поду, т.е. на нижней поверхности в печи [3], вот водка зорная, получившая свое наименование от растения луговая зоря [4]. Примечательно, что перечисление блюд идет в порядке их подачи гостям [5].

Лексика рассказа изобилует историзмами и архаизмами, значение которых без специального словаря или исторического экскурса современному читателю непонятны. Так, в примере «Ни казанские татары, ни лисовчики, ни сообщники Разина не могли взять тех твердынь, хоть не раз пытались овладеть Заборским монастырем» [1, с. 4] устаревшее слово лисовчики обозначает польскую легкую конницу [6].

Хлыстовский «кораблем» из примера «... масонских ложах да в хлысттовском корабле Татариновой малую толику деньжонок ухлопал» [1, с. 12] называлась община представителей одной из старых форм русского сектантства - христоверов [7]. 
В предложении «На ту пору дверь распахнулась, четыре лакея, каждый в сажень ростом» [1, с. 41] встречаем старинную меру длины - сажень, равнявшуюся трём аршинам [2,13 м]. Так же и во фразе «...стерляди такие, какие в нонешни годы и не ловятся: от глаза до пера два аршина и больше» [1, c. 42]. Аршином называлась русская мера длины, равная 0,711 метра [8].

В выражении «...барышни сидят в пудрамантах» [1, с. 43] варваризм пудрама́нт [«пудроманте́ль»] обозначал легкую накидку, надевавшуюся на плечи во время пудрения лица, головы [8].

Во фразе «...на щеках мушки налеплены, сама в помпадуре на фижмах» [1, с. 44] галлицизм помпадур восходит к имени фаворитки французского короля Людовика XV маркизы Помпадур [9]. Фижмами называлась юбка на китовых усах [4].

Среди архаизмов в рассказе представлены:

1] фонетические - родословное древо [1, с. 8], ярмонка [1, с. 26], раскольщики (раскольники) [1, с. 40], инбирное варенье [1, с. 45]; устерсы вместо устрицы [1, с. 61], свейский [1, с. 63], т.е. шведский [10].

2] акцентные (дО сорока) [1, с. 13].

3] словообразовательные [зачнут собираться [1, с. 27], благоцветущие $[1$, с. 12], супротив вместо против [1, с. 15], изволил [1, с. 22] и другие.

4] морфологические: «Только услыхал про это, ту ж минуту на конь, прискакал на ярмонку» [1, с. 31]. Оборот на́ конь (устар.) синонимичен обороту по ко́ням [11].

Встречается устаревшие словоформы: холопи вместо холопы; употребление слова пиит в форме женского рода: «...nиита с виршами придет [...] Жил пиита на всем на готовом» [1, с. 37].

Концепт «старина» актуализируют бесприставочные глаголы с суффиксами -ива-, -ыва- со значением «давнопрошедшее время», обозначающие неоднократную повторяемость действий, событий в прошлом или отдаленность совершаемого в прошлом действия от момента речи: сиживали, бывали, сказывали, обедывало, езжал, не бирал, видали и под., устаревшая форма причастия: «Иван Тихоныч подметил раз друга своего во пьяном образе лежаща...» [1, с. 37], усеченная форма прилагательных: стары годы, куиу лошаденку, каку-то чухонску одноколку [1, с. 19].

Частотны сематнические архаизмы: «...бывали Заборовские в ответе у цесаря римского... [1, с. 9], где клише быть в ответе означало быть в послах; «Единственный его сын, князь Алексей Юрьич, большой службы не сослужил, 
а в случае бывал» [1, с. 9]. Из контекста понятно, что выражение бывать в случае означало быть везунчиком: «И когда правительственные перемень сопровождались казнями и ссылками, благополучие князя Алексея Юрьича оставалось неизменным: чины и деревни летели к нему при каждой перемене» [1, c. 9].

В примере «Ведомость пришла, что прусский король подымается» $[1$, с. 74$]$ слово ведомость используется в значении «новость, известие».

Архаическое употребление слова подлый встречаем во фразе «A для подлого народу в сторонке сорокоуша готова» [1, с. 48]. В старые времена подлым народом назывался черный, простой люд, неимущие слои населения (крестьяне, рабочие, ремесленники и т.п.) [12].

Встречаются собственно лексические архаизмы «... заложат куиу лошаденку в каку-то чухонску одноколку» [1, с. 19]. Этноним чухонць - старое народное название эстонцев, а также карело-финского населения окрестностей Петербурга.

В примере «Тут писано про черепокожных, сиречь про устерсы, черепахи, раки и улитки, яже акридами нарииаются〉 [1, с. 61] слово сиречь союзная частица, синонимичная современным вариантам а именно, то есть, иными словами [8], слово нарищаются - устаревший синоним слова называются.

Исторический колорит придают рассказу и экзотизмы: «Одет был он 6 старинный чекмень с золотым галуном» [1, с. 14]. Чекмень - верхняя татарская одежда, похожая на казакин [13].

В этом определении следует пояснить и слово казакин. Им обозначался полукафтан с борами, прямым воротником, без пуговиц, на крючках [4].

Во фразе «...кто хочет идти на заработки - вылать паспорты» [1, с. 14] встречаем устаревшее употребление слова паспорт. Паспортом в прошлом называлось подорожное, пропускное письмо, документ, свидетельствующий личность предъявителя или его право на отлучку [9]. Попутно отметим устаревшее окончание -Ы.

В рассказе широко представлена специальная лексика из охотничьего промысла, церковного, поварского, конного или иного дела. Так, в примере « $A$ ведь и в законе написано, что столбовому барину шестериком ездить следует [1, с. 19] употреблен специальный термин шестерик, т.е. упряжка в шесть лошадей [14]. 
В примере «Ста полтора русаков заполевали» $[1$, с. 22$]$ таким специальным словом является лексема заполевать, в охотничьем промысле означавшая добыть на охоте в поле зверя [4].

В контексте предложения «И, заливаясь слезами, повалился в ноги архимандриту, ноги у него и срачииу иелует, а сам так и рыдает» [1. с. 58] специальное слово срачица означает исподнюю одежду церковнослужителя [4].

В рассказе старожила Заборья Прокофьича перемежаются народные поговорки, пословицы, диалектные и просторечные словечки, передающие очарование старорусской речи: ... пойдет стряпня рукава стряхня [1. с. 48], две коклюшки с половиной [1, с. 49], Вина капли в рот не бирал [1, с. 68], резака делать [1, с. 22], почал таскаться [1, с. 20], все то состарилось, а состарившись примерло!..[1, с. 46]. спервоначалу, спроведал, зачнут (начнут), посередь, опричь [кроме], сам-от [постфикс -от северного наречия], супротив (против), остамел (вост. остолбенеть) [4]: «Да, взглянув на сноху, так и остамел» [1, с.72].

Проведя комплексный лингвостилистический анализ народного и литературного пластов языка рассказа П.И. Мельникова-Печерского «Старые годы», можно прийти к заключению о том, что в формировании концепта «старина» задействованы все пласты русского языка - архаизмы и историзмы, варваризмы, экзотизмы, специальные слова и выражения, просторечная и диалектная лексика, фразеологизмы, пословицы и поговорки и многие другие, которые в комплексе формируют ядерные и периферийные семы концепта «старина» - от представления старины как золотого времени в изложении Прокофьича до ее кардинально противоположного восприятия рассказчиком и читателем как уродства жизненного уклада Алексея Юрьевича Заборовского.

\section{Список литературы}

1. Печерский Андрей [Мельников П.И] Старые годы: Рассказы и очерки / Сост. И примеч. А.А. Макарова. - М.: Моск. рабочий, 1986.- 544 с.

2. Азбука ремёсел: подновские огурцы // http://letopisi.ru/index.php

3. Подовые* пироги - рецепт 1870 года // https://pirogi499.ru/recepts/ retsept-podovykh-pirogov/

4. Даль В.И. Толковый словарь живого великорусского языка: В 4 т. Спб., 1863-1866. 
5. Шипилов А.В. Русская бытовая культура: пища, одежда, жилище [с древнейших времен до XVIII века]: монография. - Воронеж: ВГПУ, 2007. 567 c.

6. Энциклопедический словарь Ф.А. Брокгауза и И.А. Ефрона [В 5 тт.] / Ред.: Андреевский И.Е., Арсеньев К.К., Петрушевский Ф.Ф. - М.: Аутопан, 1998 [Электронное издание] https://dic.academic.ru/dic.nsf/brokgauz_efron

7. Ефремова Т.Ф. Современный толковый словарь русского языка. В 3 томах.- АСТ, Астрель, Харвест, Lingua. - 2005

8. Толковый словарь русского языка / Под ред. Д.Н. Ушакова. - М.: Гос. ин-т "Сов. энцикл."; ОГИЗ; Гос. изд-во иностр. и нац. слов. 1935-1940

9. Епишкин Н.И. Исторический словарь галлицизмов русского языка. Словарное издательство ЭТС, Москва, 2010.

10. Александрова 3. Е. Словарь синонимов русского языка. Практический справочник. М.: Русский язык. - 2011

11. Словарь русского языка: В 4-х т. / РАН, Ин-т лингвистич. исследований; Под ред. А.П. Евгеньевой. - 4-е изд., стер. - М.: Рус. яз.; Полиграфресурсы, 1999

12. Этимологический словарь русского языка: в 4 т./ М. Фасмер ; пер. с нем. и дополнения О.Н. Трубачева. - 4-е изд., стереотип. - М.: Астрель; М.: ACT, 2003.

13. Словарь иностранных слов, вошедших в состав русского языка. Чудинов А.Н., 1910. Словарь иностранных слов русского языка https://punktuaciya.academic.ru/searchall.php?SWord

14. Ожегов С.И. Толковый словарь русского языка / С. И. Ожегов; под общ. ред. Л. И. Скворцова. - 28-е изд., перераб. - Москва : Мир и Образование : ОНИКС, 2012. - 1375, [1] с. 